Tersedia online di: http://ejournal-balitbang.kkp.go.id/index.php/bawal
e-mail:bawal.puslitbangkan@gmail.com
BAWAL widYA RISET PERIKANAN TANGKAP
Volume 8 Nomor 2 Agustus 2016
p-ISSN: 1907-8226
e-ISSN: 2502-6410
BAWALAL
Nomor Akreditasi: 620/AU2/P2MI-LIPI/03/2015

\title{
KEMATIAN MASSAL IKAN DAN SEBARAN PARAMETER KUALITAS AIR DI TELUK JAKARTA
}

\section{MASS FISH KILLS IN JAKARTA BAY AND WATERS QUALITY PARAMETERS IN JAKARTA BAY}

\author{
Masayu Rahmia Anwar Putri*1, Sri Turni Hartati ${ }^{2}$ dan Fayakun Satria ${ }^{3}$ \\ ${ }^{1}$ Balai Penelitian Pemulihan dan Konservasi Sumberdaya Ikan, Jl. Cilalawi No. 1, Jatiluhur, Purwakarta \\ ${ }^{2}$ Pusat Penelitian dan Pengembangan Perikanan, Jl. Pasir Putih II Ancol Timur, Jakarta Utara \\ ${ }^{3}$ Balai Penelitian Perikanan Laut, Jl. Muara Baru Raya No.62, RT.21/RW.17, Penjaringan, Jakarta Utara \\ Teregistrasi I tanggal: 26 Februari 2016; Diterima setelah perbaikan tanggal: 28 Juli 2016; \\ Disetujui terbit tanggal: 04 Agustus 2016
}

\begin{abstract}
ABSTRAK
Berbagai jenis ikan, dengan bobot total lebih dari $650 \mathrm{~kg}$ ditemukan mati di pesisir Pantai Ancol tanggal 30 November 2015, diantaranya yang dominan adalah gulamah (Scianidae). Kematian ikan yang sering terjadi akan menyebabkan kerugian ekonomi yang signifikan. Identifikasi faktor penyebab terjadinya peristiwa ini sangat penting untuk diketahui dalam rangka pengelolaan populasi ikan dan penyusunan tindakan pencegahan sehingga bisa mengurangi frekuensi dan besarnya tingkat kematian ikan. Penelitian ini bertujuan untuk mengetahui sebaran spasial beberapa parameter kualitas airguna mengidentifikasi faktor penyebab kematian masal ikan di Teluk Jakarta yang terjadi pada tanggal 30 November 2015. Pengamatan dilakukan pada tanggal 1-3 Desember 2015 di 14 stasiun penelitian mencakup14 parameter fisika, kimia dan biologi perairan. Sebaran spasial beberapa parameter perairan dipetakan dengan menggunakan software ArcGIS 9.3. Parameter perairan (kedalaman, kecerahan, suhu air, pH, oksigen terlarut dan ORP (Oxidation Reduction Potential)) diukur secara insitu dan contoh air permukaan diambil untuk pengamatan plankton serta parameter kimia air di laboratorium (nitrat, fosfat, ammonia, biochemical oxygen demand, total suspended solid, sulfide dan bahan organik terlarut). Berdasarkan analisa dari 14 parameter fisika, kimia dan biologi perairan diketahui faktor penyebab kematian masal ikan di Teluk Jakarta pada 30 November 2015 disebabkan karena rendahnya kandungan oksigen terlarut $(0,07 \mathrm{mg} / 1$ pada lokasi pusat kematian ikan),kadar nutrien yang berlebihan(nitrat,0,003-0,389 mg/l dan fosfat $0,811-1,653 \mathrm{mg} / 1$,)dan tingginya konsentrasi ammonia yang merupakan gas beracun dan berbau $(0,227-1,944 \mathrm{mg} / \mathrm{l})$.
\end{abstract}

Kata Kunci: Kematian ikan; nutrient; oksigen terlarut; Teluk Jakarta

\section{ABSTRACT}

On November $30^{\text {th }}$, 2015, more than $650 \mathrm{~kg}$ fishes found dead in the coast of Ancol. The identification of its causes is very vital to develop mitigation for managing fish population and preventing economic loss. This study aims to examine several waters parameters to identify the factors causing mass deaths of fish. The study was conducted on 1-3 December 2015 in Jakarta Bay by analyzing 14 parameters of physical, chemical and biological aspect. Spatial distribution of water parameters mapped using ArcGIS 9.3 software. Some water parameters were measured in situ (depth, brightness, water temperature, $\mathrm{pH}$, dissolved oxygen and ORP (oxidation reduction potential) while surface water samples were taken and analyzed in the laboratory (Nitrate, phosphate, ammonia, biochemical oxygen demand. The result showed that a mass fish kills in Jakarta Bay on 30 November 2015 due to low dissolved oxygen content, release of toxic gas into the water, excessive nutrient and high ammonia.

Keywords: Fish kills; distribution; nutrient; dissolved oxygen; Jakarta Bay 


\section{PENDAHULUAN}

Peristiwa kematian masal ikan cukup sering terjadi di Indonesia, tetapi biasanya terjadi di perairan tawar tergenang seperti danau dan waduk (Erlania et al., 2010; Nasution et al., 2011; Suryati \& Samuel, 2012; Rahmani et al., 2011; Suryanto, 2015). Kematian masal ikan yang terjadi di beberapa waduk Indonesia, disebabkan oleh naiknya massa air bagian bawah ke permukaan, sehingga limbah hasil kegiatan budidaya berupa bahan organik ikut naik ke permukaan (upwelling) (Kartamihardja, 2013). Kematian masal ikan seperti yang terjadi pada November 2015 di Teluk Jakarta, pernah terjadi di Teluk Lampung pada 2013 dan di Teluk Jakarta pada 2004 dan 2005 yang disebabkan oleh fenomena Harmful Algal Blooms (HABs), ledakan plankton jenis Skeletonema costatum dan penurunan kandungan oksigen (Irawan et al., 2015; Sachoemar \& Wahjono, 2007).

Kematian masal ikan bisa disebabkan oleh beberapa faktor seperti kadar oksigen terlarut yang rendah, pertumbuhan alga yang berlebihan, perubahan suhu perairan secara mendadak, parasit, penyakit serta polusi (Meyer \& Barclay, 1990; Pidgeon, 2001; Anonim, 2003; La \& Cooke, 2011). Holmlund \& Hammer (1999) menyatakan kematian ikan yang sering terjadi dapat menyebabkan kerugian ekonomi yang signifikan dan jika dalam jumlah besar akan berdampak negatif pada tatanan dinamika rantai makanan dan keseimbangan nutrien.

Suprapto et al., (2011) telah mengkaji kondisi lingkungan Teluk Jakarta, diantaranya bahwa perairan Teluk Jakarta merupakan perairan dangkal dengan kecerahan relatif rendah, angin musim memberikan pengaruh yang nyata terhadap pola sebaran parameter kualitas masa air. Karakteristik perairan Teluk Jakarta dipengaruhi oleh sirkulasi masa air Laut Jawa dan sungai yang berlangsung secara periodik sesuai perubahan musim. Hasil indeks keanekaragaman bentos menunjukkan bahwa Teluk Jakarta memiliki tingkat pencemaran ringan sampai berat. Secara ekologis perairan Teluk Jakarta tergolong perairan dengan tingkat pencemaran tinggi berkaitan dengan tingginya masukan bahan organik (KPPL, 1997) dan unsur logam berat (Yatim et al., 1979; Lestari\& Edward, 2004).
Kematian masal ikan yang terjadi di Teluk Jakarta ditunjukkan dengan adanya penumpukan bangkai berbagai jenis biota perairan seperti ikan, udang dan rajungan di pesisir Pantai Ancol pada 30 November 2015. Berbagai jenis sumber daya ikan, dengan bobot total diperkirakan lebih dari $650 \mathrm{~kg}$ ditemukan mati.

Dugaan penyebab terjadinya kematian masal ikan di pantai Ancol pada November 2015 yang dilaporkan mayarakat, mulai dari masukan limbah domestik dan industri serta ledakan populasi plankton. Penentuan penyebab kematian ikan pada dasarnya cukup sulit dilakukan, tetapi mengetahui faktor penyebab terjadinya peristiwa kematian ikan sangat penting dilakukan dalam rangka pengelolaan sumber daya ikan dan antisipasi pencegahannya sehingga dapat mengurangi frekuensi dan besarnya tingkat kematian ikan (Thronson \& Quigg, 2008 dan La \& Cooke, 2011). Penelitian ini bertujuan untuk mengetahui faktor penyebab kematian massal ikanyang terjadi pada 30 November 2015 melalui analisis sebaran sepasial parameter kualitas air Teluk Jakarta.

\section{BAHAN DAN METODE}

Pengukuran dan pengambilan sampel parameter fisika, kimia dan biologi perairan di lakukan pada 1-3 Desember 2015 di 14 stasiun penelitian di perairan Teluk Jakarta (Tabel 1). Parameter perairan diukur secara insitu(kedalaman, kecerahan, suhu air, $\mathrm{pH}$, oksigen terlarut dan ORP) dan dilakukan juga pengambilan sampel air permukaan untuk pengamatan fitoplankton serta parameter kimia air yang akan dilakukan di laboratorium(Tabel 2). Pengamatan fitoplankton dilakukan pada 5 stasiun (st.1, st.5, st.8, st.10 dan st.11), dengan cara menarik net plankton sejauh 10 meter (diameter mulut jaring 0,30 m, mess size : $60 \mu \mathrm{m}$ ), kelimpahan dan komposisi jenis plankton dianalisa di laboratorium BP2KSI dengan metode dan petunjuk referensi kunci identifikasi (Yamaji, 1996). Identifikasi jenis-jenis ikan yang mati di lakukan oleh Laboratorium Dinas Perikanan dan Kelautan Jakarta Utara, mengacu pada Tarp \& Kailola (1979). Pengamatan parameter kimia air seperti ammonia, bahan organik terlarut dan sulfide dilakukan pada delapan stasiun yang mewakili masingmasing lokasi penelitian. Gambar 1 menampilkan peta lokasi pengamatan kualitas air oleh tim Balai Penelitian Pemulihan dan Konservasi Sumberdaya Ikan(BP2KSI). 
Tabel 1. Nama lokasi dan koordinat stasiun penelitian Table 1. Location names and research station coordinates

\begin{tabular}{clccc}
\hline No & Lokasi/location & $\begin{array}{c}\text { kode stasiun/ } \\
\text { station code }\end{array}$ & $\begin{array}{c}\text { Lintang/ } \\
\text { latitude }\end{array}$ & $\begin{array}{c}\text { Bujur/ } \\
\text { longitude }\end{array}$ \\
\hline 1 & Tj. Kait & 1 & -6.0129 & 106.6809 \\
& & 2 & -6.0150 & 106.6890 \\
2 & Tj. Pasir & 3 & -6.0424 & 106.7148 \\
& & 4 & -6.0272 & 106.7135 \\
3 & Muara Kamal & 5 & -6.0904 & 106.7269 \\
& & 6 & -6.0616 & 106.7373 \\
& & 7 & -6.0471 & 106.7468 \\
4 & Muara Baru & 8 & -6.1112 & 106.8070 \\
& & 9 & -6.0961 & 106.8046 \\
5 & Muara Ancol & 10 & -6.1174 & 106.8286 \\
6 & Pantai Ancol & 11 & -6.1175 & 106.8483 \\
7 & Tj. Priuk & 12 & -6.0817 & 106.9140 \\
8 & Muara Cilincing & 13 & -6.0967 & 106.9397 \\
& & 14 & -6.0872 & 106.9358 \\
9 & Muara Angke & $\mathrm{a}$ & -6.0979 & 106.7630 \\
10 & Putri Duyung & $\mathrm{b}$ & -6.1182 & 106.8447 \\
\hline
\end{tabular}

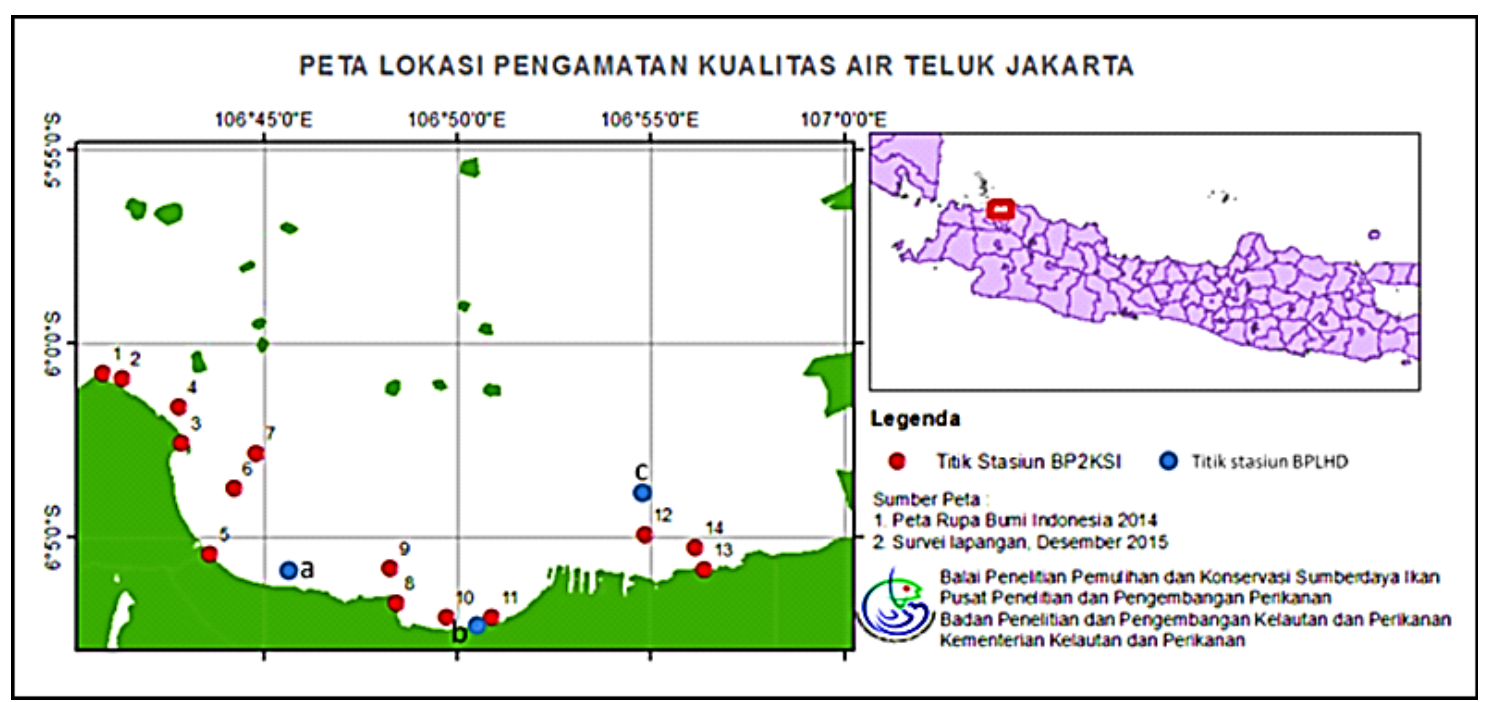

Gambar 1. Lokasi penelitian.

Figure 1. Research location. 
Tabel 2. Parameter perairan yang diukur, alat serta metode yang digunakan

Table 2. Water parameters measured, tools and methods used

\begin{tabular}{|c|c|c|c|c|}
\hline No & Parameter/parameters & Satuan/unit & $\begin{array}{l}\text { Alat/metode yang digunakan } \\
\text { Equipment/methods used }\end{array}$ & $\begin{array}{c}\text { Lokasi analisis } \\
\text { sampel/Sample } \\
\text { analysis location }\end{array}$ \\
\hline 1 & Kedalaman air & $\mathrm{m}$ & Depth Metre, in situ & - \\
\hline 2 & Kecerahan & $\mathrm{cm}$ & Cakram Secchi, in situ & - \\
\hline 3 & Suhu air & ${ }^{\circ} \mathrm{C}$ & Water Quality Checker, in situ & - \\
\hline 4 & $\mathrm{pH}$ & unit & Water Quality Checker, in situ & - \\
\hline 5 & Oksigen Terlarut & $\mathrm{mg} / \mathrm{l}$ & Water Quality Checker, insitu & - \\
\hline 6 & Salinitas & $\%$ & Refraktometer, insitu & - \\
\hline 7 & ORP & $\mathrm{mV}$ & Water Quality Checker, insitu & - \\
\hline 8 & Nitrat $\left(\mathrm{NO}_{3}\right)$ & $\mathrm{mg} / \mathrm{l}$ & Brucine, spektofotometri & $\begin{array}{l}\text { Lab. Kimia Air } \\
\text { BP2KSI }\end{array}$ \\
\hline 9 & Ortho posfat $\left(\mathrm{PO}_{4}\right)$ & $\mathrm{mg} / \mathrm{l}$ & SNI 06-69.89.31-2005 & $\begin{array}{l}\text { Lab. Kimia Air } \\
\text { BP2KSI }\end{array}$ \\
\hline 10 & Ammonia $\left(\mathrm{NH}_{3}\right)$ & $\mathrm{mg} / \mathrm{l}$ & SNI 19-6964.3-2003 & Bogor Labs \\
\hline 11 & $\begin{array}{l}\text { Biochemical Oxygen Demand } \\
\left(\mathrm{BOD}_{5}\right)\end{array}$ & $\mathrm{mg} / \mathrm{l}$ & APHA $21^{\text {st }}, 5210 \mathrm{~B}$ & Bogor Labs \\
\hline 12 & Total suspended solid(TSS) & $\mathrm{mg} / \mathrm{l}$ & Gravimetri & $\begin{array}{l}\text { Lab. Kimia Air } \\
\text { BP2KSI }\end{array}$ \\
\hline 13 & Sulpida, $\mathrm{S}^{2-}$ (as H2S) & $\mathrm{mg} / 1$ & SNI 19-6964.4-2003. & Bogor Labs \\
\hline 14 & $\begin{array}{l}\text { Bahan Organik Terlarut } \\
\left(\mathrm{KMnO}_{4}\right)\end{array}$ & $\mathrm{mg} / \mathrm{l}$ & Permanganat, Titrimetri & $\begin{array}{l}\text { Lab.Kimia Air } \\
\text { BP2KSI }\end{array}$ \\
\hline 15 & Fitoplankton & $\operatorname{sel} / 1$ & $\begin{array}{l}\text { Pengambilan sampel fitoplankton } \\
\text { dikumpulkan dengan menggunakan } \\
\text { fitoplankton net berbentuk kerucut } \\
\text { yang mempunyai diamater mulut } \\
31 \mathrm{~cm} \text {, panjang } 100 \mathrm{~cm} \text { dan ukuran } \\
\text { mata jaring } 0.08 \mathrm{~mm}(80 \mathrm{um}) \text {. } \\
\text { Planktonet ditarik di permukaan } \\
\text { perairan dengan menggunakan tali } \\
\text { sepanjang } 10 \mathrm{~m} \text {. Pengamatan jenis } \\
\text { dan penghitungan kelimpahan } \\
\text { plankton menggunakan mikroskop } \\
\text { binokuler dengan pembesaran } 100 \\
\text { kali dan mengacu pada buku } \\
\text { Yamaji (1996) }\end{array}$ & $\begin{array}{l}\text { Lab. Plankton } \\
\text { BP2KSI }\end{array}$ \\
\hline
\end{tabular}

Selain pengukuran parameter lingkungan, dilakukan juga pengumpulan data dan informasi tentang cuaca, angin dan pasang surut di wilayah Jakarta seperti suhu udara selama periode November didapatkan dari www.accuweather.com, kondisi angin pada $29-30$ November 2015 (arah dan kecepatan angin) didapatkan dari Badan Meteorologi, Klimatologi dan Geofisika (BMKG) Stasiun Meteorologi Maritim Klas I Tanjung Priok dan informasi pasang surut didapatkan dari Dinas HidroOseanografi TNI Angkatan Laut (DISHIDROS TNI AL). Sebaran spasial beberapa parameter perairan dipetakan dengan menggunakan software ArcGIS 9.3.

\section{HASIL DAN BAHASAN Hasil}

Identifikasi jenis-jenis ikan yang mati di perairan Ancol, Teluk Jakarta adalah kelompok ikan demersal yang didominasi oleh Gulamah/Jewfishes (Scianidae) dan beseng-beseng/cardinalfish (Apogonidae) hampir 50\%, dan jenis-jenis ikan lainnya, seperti seperti kipper/spotted scat (Scatophagus argus), beronang/Rabbitfishes (Siganidae), petek/Ponyfishes (Leiognathidae), Sembilang karang/Eeltailed catfish (Plotosidae), rajungan/ blue swimmer crab (Portunidae) dan ikan-ikan berukuran kecil lainnya. Ikan-ikan tersebut biasanya tertangkap oleh bagan tancap dan sero yang dioperasikan dan tersebar di sepanjang pantai barat dan timur Teluk Jakarta. Selain ikan, $\pm 30 \mathrm{~kg}$ udang estuari yang mengapung di perairan Muara Kamal pada 28-30 November 2015 diantaranya udang windu/tiger shrimp (Penaeus monodon), udang putih/white shrimp (P. indicus) dan udang dogol/ endeavour/brown shrimp (Metapenaeus ensis).

Terdapat 14 parameter perairan yang diamati dalam penelitian untuk menentukan faktor penyebab kematian 
massal ikan yang terjadi pada 30 November 2015 (Tabel 3). Parameter perairan seperti kecerahan, suhu air, $\mathrm{pH}$, salinitas, TSS, BOD ${ }_{5}$, sulpida dan plankton di Teluk Jakarta tidak menunjukkan perbedaan yang signifikan antar masing-masing stasiun dan masih berada dalam kondisi umum untuk perairan Teluk Jakarta. Kecerahan perairan di lokasi penelitian berkisar antara 0,5-2,9 $\mathrm{m}$ dengan suhu air antara $31-33,6^{\circ} \mathrm{C}$. Nilai salinitas berkisar antara 27,73$34,28 \%$ o dengan $\mathrm{pH}$ perairan antara 7,6-8,62. Konsentrasi TSS berkisar 8-39 mg/l, BOD ${ }_{5}$ antara 6,53-12,24 mg/l dan konsentrasi sulfida kurang dari 0,008 mg/l. Tetapi beberapa parameter lainnya menunjukkan nilai yang ekstrim, seperti oksigen terlarut, ORP, nitrat, fosfat, ammonia dan bahan organik terlarut.

Tabel 3. Parameter kualitas perairan permukaan di stasiun penelitianTeluk Jakarta pada tanggal 1-3 Desember 2015 Table 3. Water quality parameters in Jakarta Bay in 1-3 Dec 2015

\begin{tabular}{cccccccc}
\hline $\begin{array}{c}\text { Kode } \\
\text { stasiun/station } \\
\text { code }\end{array}$ & $\begin{array}{c}\text { Kedalaman } \\
\text { air/Water } \\
\text { depth } \\
(\mathbf{m})\end{array}$ & $\begin{array}{c}\text { Kecerahan/ } \\
\text { transparency } \\
\mathbf{( m )}\end{array}$ & $\begin{array}{c}\text { Suhu } \\
\text { air/water } \\
\text { temperature }\end{array}$ & $\mathbf{p H}$ & $\begin{array}{c}\text { Salinitas/ } \\
\text { salinity } \\
\mathbf{( \% )}\end{array}$ & $\begin{array}{c}\text { Oksigen } \\
\text { terlarut/Dissolv } \\
\text { ed oxygen(mg/l) }\end{array}$ & $\begin{array}{c}\text { ORP } \\
(\mathbf{m V})\end{array}$ \\
\hline 1 & 1,9 & 0,5 & 31,6 & 8,52 & 33 & 8,86 & -52 \\
2 & 3,2 & 2,9 & 32,0 & 8,62 & 30 & 8,76 & $-51,5$ \\
3 & 0,9 & 0,8 & 32,4 & 8,44 & 34 & & 48,9 \\
4 & 4,5 & 2 & 31,5 & 8,53 & 34 & 9,08 & $-26,8$ \\
5 & 1,6 & 0,6 & 33,6 & 6,84 & 32,53 & 2,51 & $-59,1$ \\
6 & 7,4 & 2,9 & 31,7 & 7,61 & 32 & 3,01 & $-23,9$ \\
7 & 9,5 & 2,9 & 31,4 & 8,25 & 35 & 6,25 & $-32,9$ \\
8 & 5,2 & 1,5 & 32,6 & 8,09 & 33,9 & 8,85 & $-11,7$ \\
9 & 5,4 & 1,7 & 32,2 & 7,93 & 34,28 & 4,68 & $-26,00$ \\
10 & 2,6 & 1,6 & 32,8 & 8,08 & 34,12 & 4,51 & $-10,5$ \\
11 & 2,9 & 0,7 & 31,0 & 7,92 & 34,27 & 0,07 & -200 \\
12 & 6,9 & 1,3 & 32,0 & 8,58 & 33 & 8,01 & $-20,1$ \\
13 & 1,7 & 0,5 & 31,8 & 7,6 & 27,73 & 2,5 & $-65,5$ \\
14 & 5,4 & 1,3 & 32,6 & 8,29 & 32,98 & 8,2 & $-28,3$ \\
\hline
\end{tabular}

Tabel 3. Lanjutan parameter kualitas perairan permukaan di stasiun penelitian Teluk Jakarta pada tanggal 1-3 Desember 2015

Table 3. Water quality parameters in Jakarta Bay in 1-3 Dec 2015(continue)

\begin{tabular}{|c|c|c|c|c|c|c|c|c|}
\hline $\begin{array}{c}\text { Kode } \\
\text { stasiun }\end{array}$ & $\begin{array}{l}\text { Nitrat/ } \\
\text { Nitrate } \\
(\mathrm{mg} / \mathrm{l})\end{array}$ & $\begin{array}{c}\text { Ortoposfat/ } \\
\text { Orthophosphate } \\
\text { (mg/l) }\end{array}$ & $\begin{array}{c}\text { Ammonia/ } \\
\text { Ammonia } \\
\text { (mg/l) }\end{array}$ & $\begin{array}{l}\text { BOD5 } \\
(\mathrm{mg} / \mathrm{l})\end{array}$ & $\begin{array}{c}\text { TSS } \\
(\mathrm{mg} / \mathrm{l})\end{array}$ & $\begin{array}{c}\text { Sulpida/ } \\
\text { Sulphide } \\
\text { (mg/l) }\end{array}$ & $\begin{array}{c}\mathrm{KMnO4} \\
(\mathrm{mg} / \mathrm{l})\end{array}$ & $\begin{array}{c}\text { Kepadatan } \\
\text { Fitoplankton/ } \\
\text { phytoplankton } \\
\text { (sel/l) }\end{array}$ \\
\hline 1 & 0,087 & 1,477 & 0,227 & 7,18 & 21,67 & $<0,008$ & 5,41 & 15789 \\
\hline 2 & 0,006 & 1,109 & & & 19,33 & & 4,83 & \\
\hline 3 & 0,007 & 1,040 & 0,443 & 6,53 & 29,00 & $<0,008$ & 6,29 & \\
\hline 4 & 0,004 & 1,202 & & & 8,00 & & 4,97 & \\
\hline 5 & 0,389 & 1,449 & 0,398 & 8,98 & 27,17 & $<0,008$ & 10,24 & 6821 \\
\hline 6 & 0,039 & 1,180 & & & 22,00 & & 2,93 & \\
\hline 7 & $<0,003$ & 1,184 & & & 21,67 & & 4,54 & \\
\hline 8 & 0,028 & 1,109 & 0,533 & 11,42 & 21,00 & $<0,008$ & 7,38 & 5867 \\
\hline 9 & 0,007 & 0,865 & & & 21,33 & & 9,16 & \\
\hline 10 & 0,084 & 1,653 & 0,506 & 11,91 & 29,00 & $<0,008$ & 11,22 & 7714 \\
\hline 11 & 0,303 & 0,901 & 1,261 & 12,00 & 34,83 & $<0,008$ & 9,75 & 3029 \\
\hline 12 & 0,072 & 0,883 & 0,191 & 12,24 & 36,75 & $<0,008$ & 11,52 & \\
\hline 13 & 0,268 & 0,811 & 1,944 & 11,75 & 39,75 & $<0,008$ & 15,36 & \\
\hline 14 & 0,012 & 0,933 & & & 31,50 & & 7,68 & \\
\hline
\end{tabular}

Kadar oksigen terlarut di lokasi penelitian menunjukkan kisaran nilai antara 0,07-9,08 mg/l, dimana kandungan oksigen terlarut di stasiun perairan Pantai Ancol (st.11) setelah kematian masal ikan menunjukkan nilai yang sangat rendah, dibandingkan dengan nilai batas ambang baku mutu menurut Kep.Men. Neg. Lingkungan Hidup No. 51 Tahun 2004 dibandingkan dengan lokasi lainnya yaitu sebesar $0,07 \mathrm{mg} / 1$. Gambar 2 menampilkan sebaran kadar oksigen terlarut di pesisir Teluk Jakarta. 


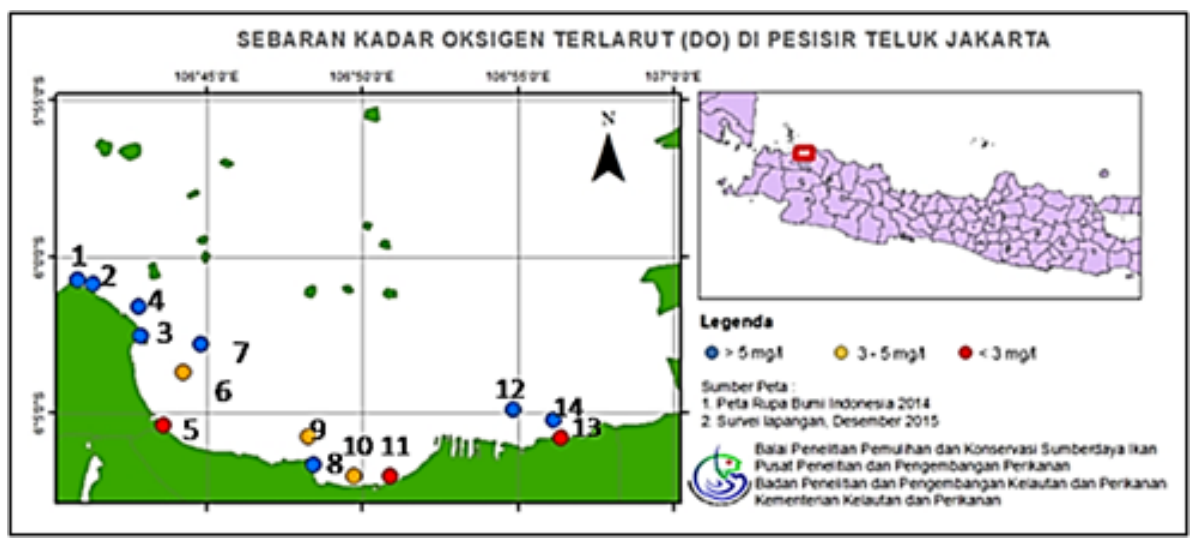

Gambar 2. Sebaran kadar oksigen terlarut.

Figure 2. Dissolved oxygen distribution.

Kandungan zat organik (KMnO4) di lokasi penelitian berkisar antara 2,93-15,36 mg/l dimana beberapa muara Teluk Jakarta, seperti Muara Kamal (st.5), Muara Ancol (st.10), Tanjung Priuk (st.12) dan muara Cilincing (st.13) menunjukkan konsentrasi yang lebih tinggi dibandingkan lokasi lainnya. Tingginya kandungan zat organik menunjukkan muara-muara Teluk Jakarta telah tercemar oleh limbah, baik domestik maupun industri (Gambar 3).
Konsentrasi nitrat di lokasi penelitian berkisar antara $<0,003-0,389 \mathrm{mg} / \mathrm{l}$, dimana konsentrasi nitrat yang tinggi ditemukan di st.5, st.11dan st.13. Konsentrasi fosfat di perairan Teluk Jakarta berkisar antara 0,811 - 1,653 mg/1, dimana semua lokasi penelitian menunjukkan kadar fosfat yang tinggi untuk perairan laut. Sebaran nitrat dan fosfat ditampilkan pada Gambar 4 dan 5.

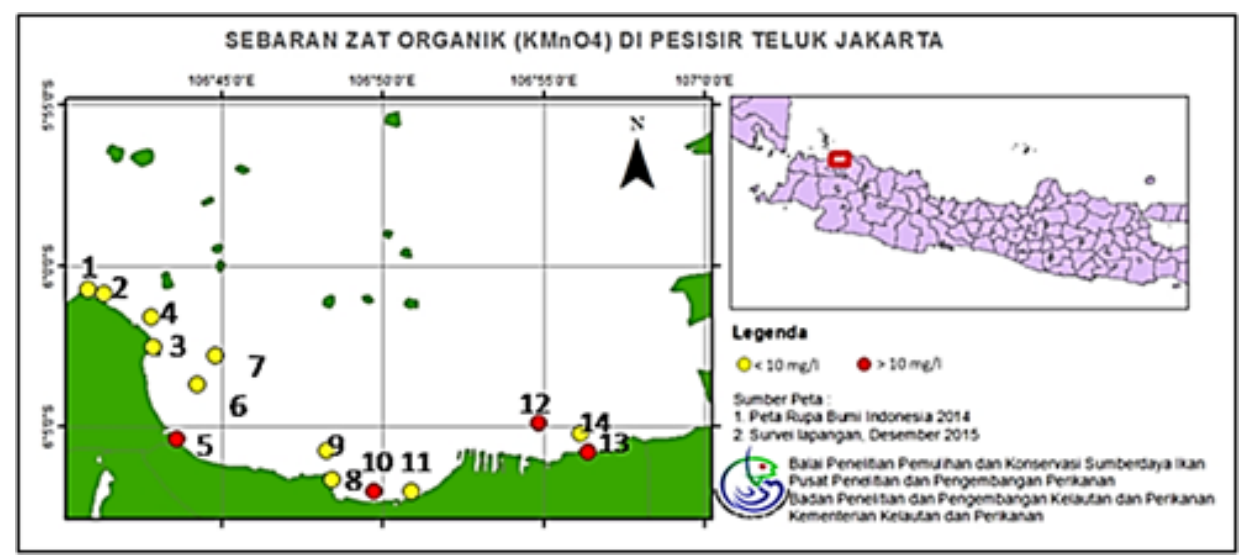

Gambar 3. Sebaran zat organik $\left(\mathrm{KMnO}_{4}\right)$.

Figure 3. Organic matter $\left(\mathrm{KMnO}_{4}\right)$ distribution.

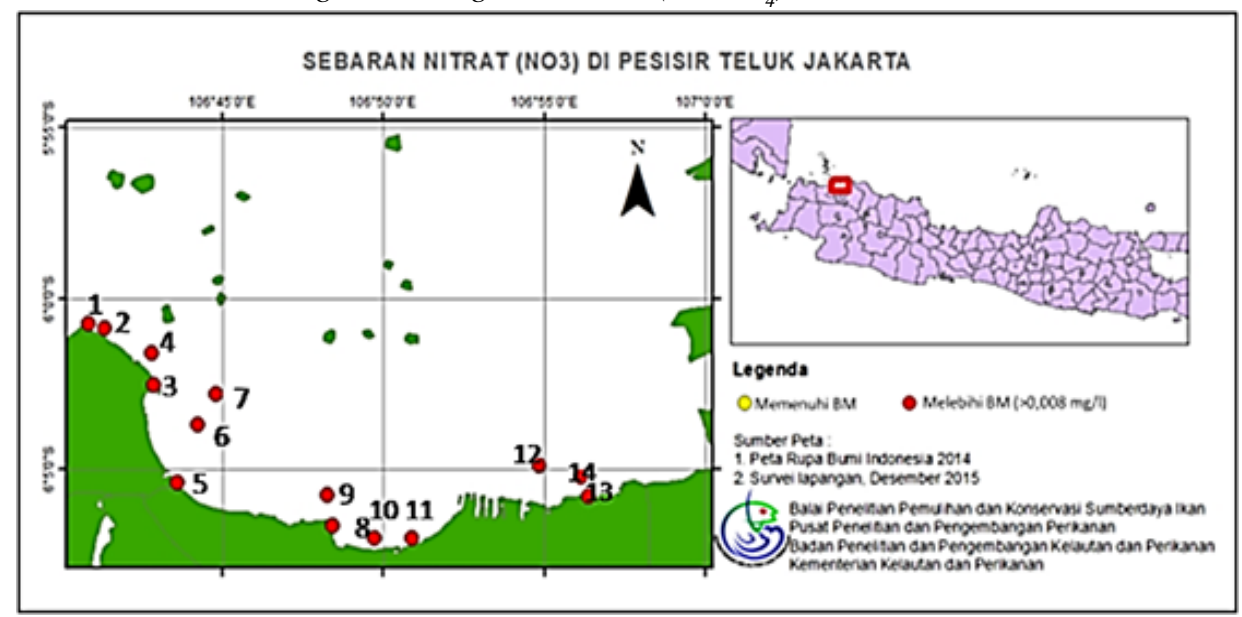

Gambar 4. Sebaran fosfat $\left(\mathrm{P}-\mathrm{PO}_{4}\right)$.

Figure 4. Phosphate $\left(\mathrm{P}-\mathrm{PO}_{4}\right)$ distribution. 


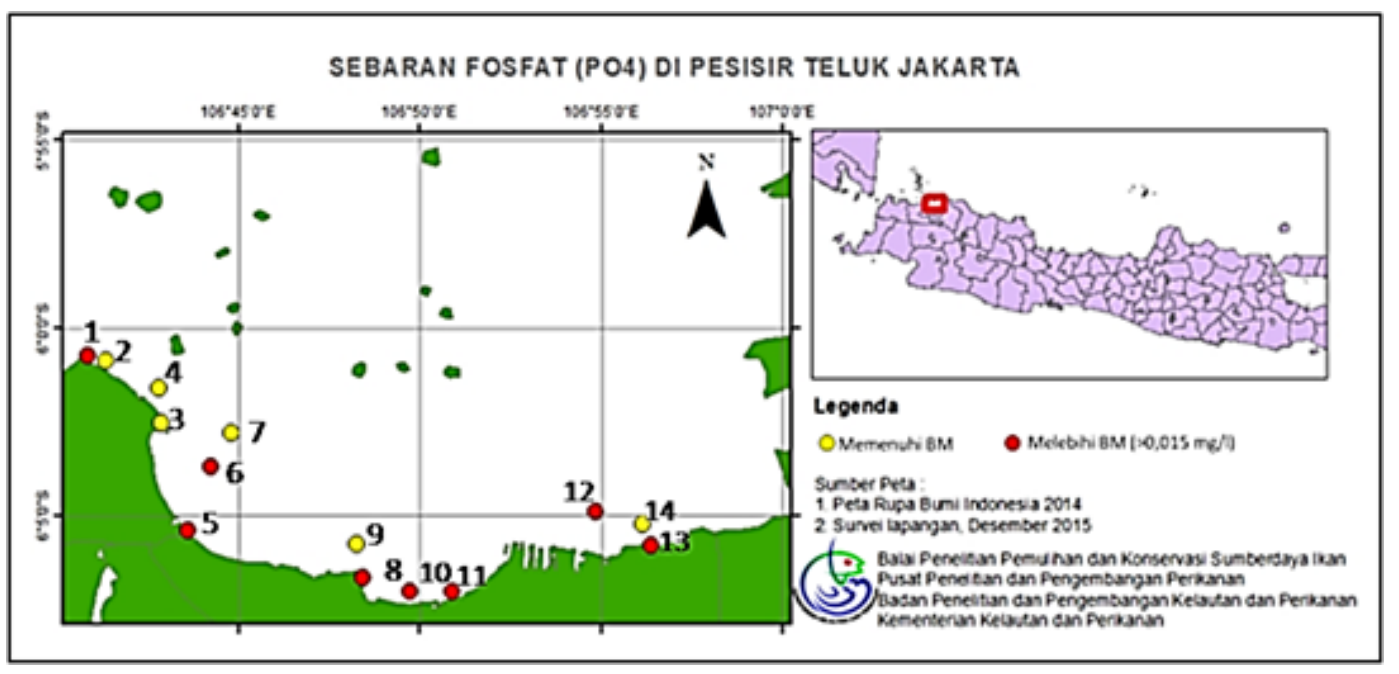

Gambar 5. Sebaran nitrat $\left(\mathrm{N}-\mathrm{NO}_{3}\right)$.

Figure 5. Nitrate $\left(\mathrm{N}-\mathrm{NO}_{3}\right)$ distribution.

Gambar 6 menunjukkan sebaran konsentrasi ammonia di lokasi penelitian. Kandungan ammonia $\left(\mathrm{NH}_{3}-\mathrm{N}\right) \mathrm{di}$ lokasi penelitian setelah kematian masal ikan berkisar antara 0,191 - 1,944 mg/l, dan hanya st.1, yaitu daerah
Tanjung kait (bagian timur Teluk Jakarta) dan Tanjung priuk (st.12) yang menunjukkan konsentrasi yang rendah, 0,227 dan $0,191 \mathrm{mg} / 1$.

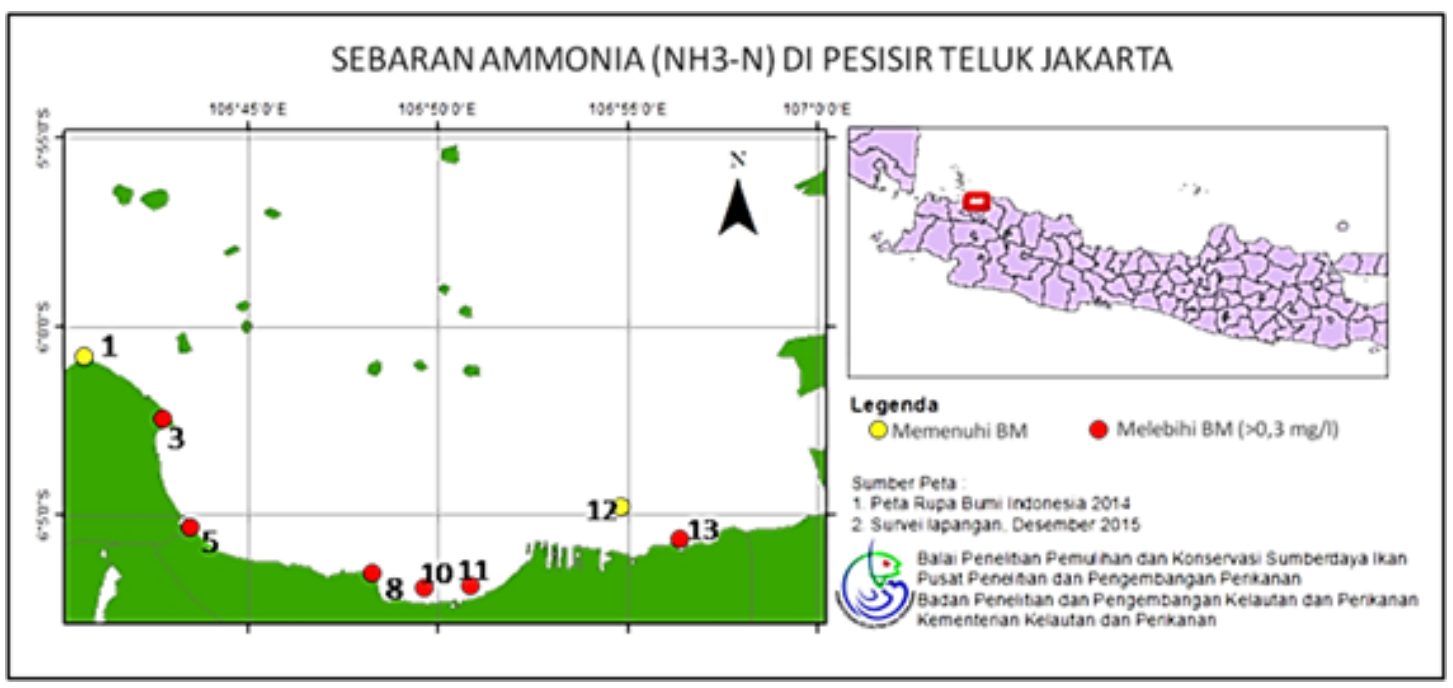

Gambar 6. Sebaran Ammonia.

Figure 6. Ammonia distribution.

Kelimpahan fitoplankton hasil pengamatan menunjukkan kondisi normal untuk perairan Teluk Jakarta, yaitu pada kisaran antara 2.908-15.690 sel/1. Hasil pemantauan rutin Teluk Jakarta yang dilakukan bersama antara Balai Penelitian Perikanan laut dan BPLHD Jakarta selama tahun 1996-2014 menunjukkan kecenderungan yang sama, yaitu kelimpahan berkisar antara $10^{3}-10^{6} \mathrm{sel} / 1$
(BPPL, 2014), dimana Kelas Bacillariophyceae selalu mendominasi komposisi fitoplankton.Gambar 7 menampilkan kelimpahan fitoplankton yang ditemukan di perairan Teluk Jakarta. Lampiran 1 menampilkan jenis-jenis fitoplankton yang ditemukan di perairan Teluk Jakarta. Teridentifikasi 26 jenis fitoplankton di perairan Teluk Jakarta yang didominasi adalah Chaetoceros sp. 
Putri, M. R. A., et al. / BAWAL. 8 (2) Agustus 2016: 77-90

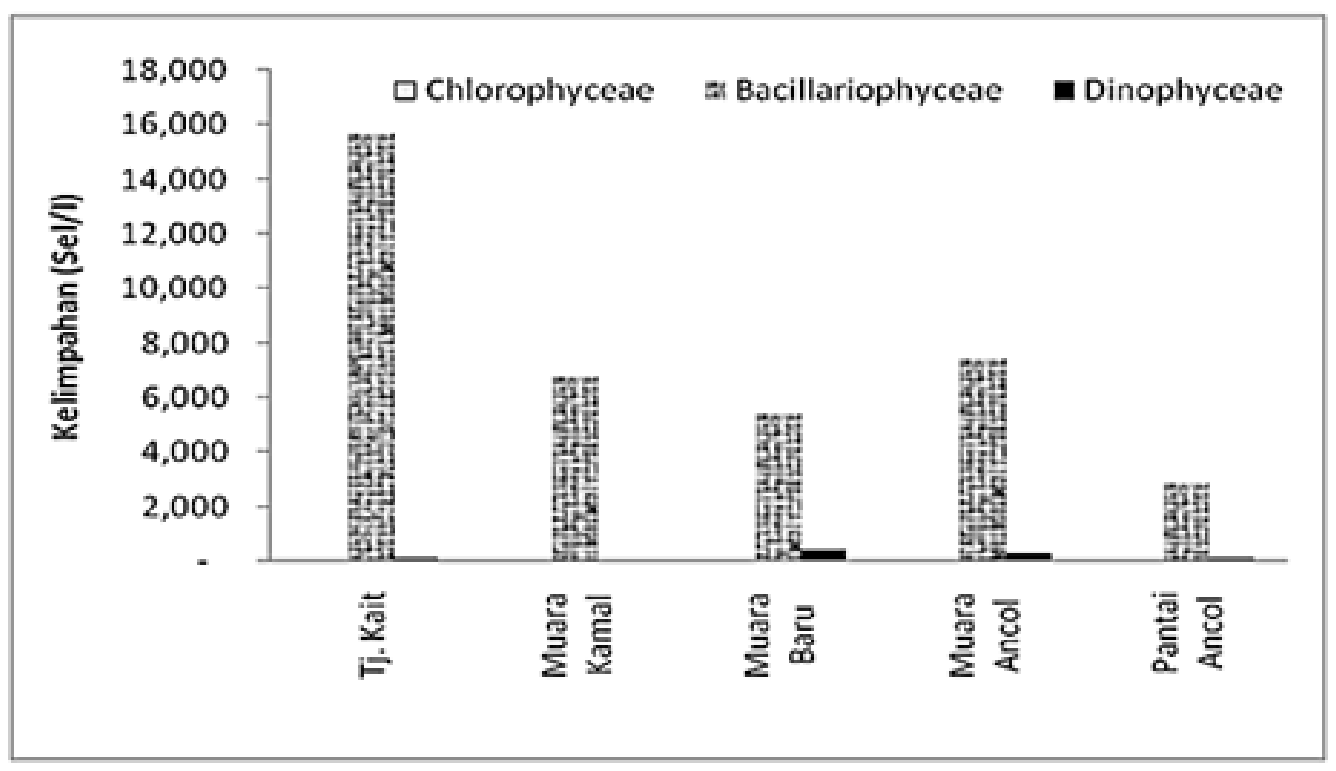

Gambar 7. Kelimpahan fitoplankton di Teluk Jakarta.

Figure 7. Phytoplankton abundance in Jakarta Bay.

\section{Bahasan}

Berdasarkan gambaran hasil yang telah diuraikan, diduga penyebab kematian massal ikan di Teluk Jakarta adalah rendahnya kandungan oksigen terlarut (Gambar 2), pelepasan gas beracun, masukan nutrien yang berlebihan dan tingginya konsentrasi ammonia (Gambar 6).

Beberapa tanda fisik kematian ikan karena rendahnya kandungan oksigen tampak terlihat saat peristiwa terjadi, adalah kesulitan bernafas dan bermunculan jenis-jenis ikan dasar ke permukaan air serta peristiwa kematian ikan yang terjadi pada pagi hari (Meyer \& Herman, 1990). Menurut Ohrel \& Register (2006), organisme hidup seringkali merasa stress ketika kadar oksigen terlarut menurun antara 3-5 mg/l dan apabila levelnya menurun hingga dibawah $3 \mathrm{mg} / \mathrm{l}$ (hypoxia), kebanyakan spesies akan pindah ke lokasi lain dan hewan yang immobile akan mati.

Perubahan suhu secara mendadak yang dapat menyebabkan perubahan densitas air terjadi di DKI Jakarta ketika kematian masal ikan berlangsung, dimana terjadi penurunan suhu sebesar $3^{\circ} \mathrm{C}$ pada tanggal 29 November $2015\left(30^{\circ} \mathrm{C}\right)$, kemudian meningkat kembali keesokan harinya $\left(33^{\circ} \mathrm{C}\right)$ disajikan pada lampiran 2 .. Perbedaan densitas yang kecil dapat menghasilkan arus laut yang kuat dan kemudian akan menyebabkan naiknya substrat dasar perairan yang mengandung gas-gas beracun. Lampiran 2 menunjukkan perubahan suhu udara di Jakarta selama periode November 2015 (www.accuweather.com, 2016).

Terciumnya bau busuk di lokasi kejadian menandakan adanya pelepasan gas hydrogen sulfide $\left(\mathrm{H}_{2} \mathrm{~S}\right)$ ke perairan.
Proses ini dapat dilihat dari nilai ORP saat penelitian (Gambar 8). ORP adalah angka yang menunjukkan tingkat kebersihan air dan kemampuannya untuk menghancurkan kontaminan. Semakin banyak kontaminan dalam air, kandungan oksigen terlarut akan semakin rendah karena bahan organik memerlukan oksigen, sehingga pada kondisi tersebut nilai ORP semakin rendah. Ketika nilai ORP semakin tinggi, maka kemampuan air untuk menghancurkan kontaminan asing seperti mikroba akan semakin besar (Anonim, 2015). Sebagian besar nilai ORP di pesisir Teluk Jakarta setelah peristiwa kematian ikan menunjukkan nilai di bawah $0 \mathrm{mV}$, dan hanya di Tanjung Pasir (st.3) yang menunjukkan nilai positif. Jika ORP dibawah angka $0 \mathrm{mV}$, menunjukkan racun hydrogen sulfide $\left(\mathrm{H}_{2} \mathrm{~S}\right)$ akan menguasai perairan (Holmes-Farley, 2008). Xu et al. (2016) menambahkan pada kondisi ini, kandungan besi (Fe) dan aluminium yang terikat fosfor (Al-P) dalam sedimen akan dilepaskan ke perairan. Nilai ORP di pantai Ancol (st.11) yang tercatat kematian ikannya cukup banyak mencapai $-200 \mathrm{mV}$, dimana pada nilai ini terjadi pembentukan sulfida dan produksi gas metan, dan bisa menyebabkan ikan mati lemas (Gerardi, 2007).

Perubahan warna air laut menjadi putih di sekitar pantai Ancol beberapa hari sebelum kematian masal ikan (Dinas Kelautan, perikanan dan Ketahanan Pangan DKI Jakarta, 2015) merupakan indikasi adanya reaksi antara hidrogen sulfide $\left(\mathrm{H}_{2} \mathrm{~S}\right)$ dan oksigen, dimana reaksi ini akan menurunkan kadar oksigen terlarut di perairan. Kondisi serupa sering terjadi di pesisir Namibia, dimana bau busuk selalu tercium di wilayah tersebut. Gas $\mathrm{H}_{2} \mathrm{~S}$ membunuh sebagian besar populasi ikan dan organisme laut lainnya (Anonim, 2010). 


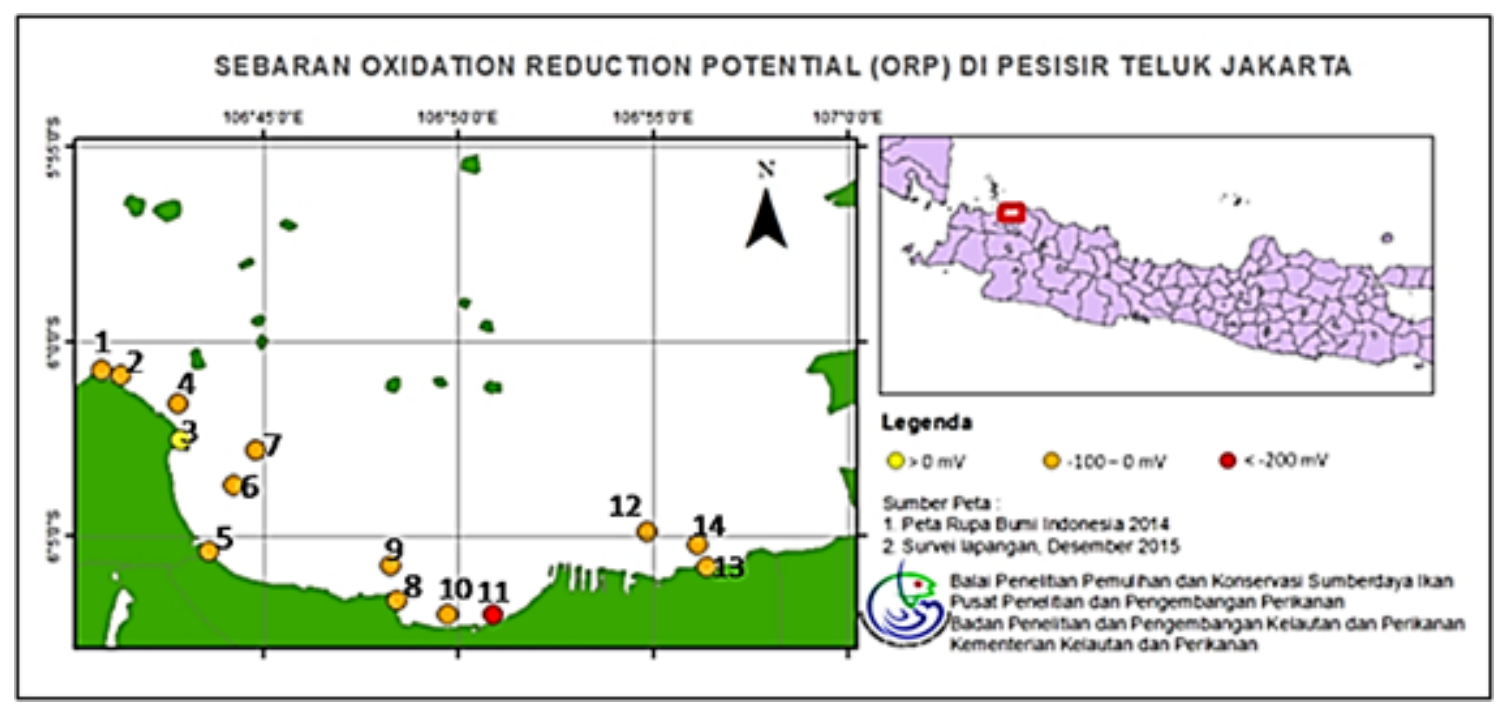

Gambar 8. Sebaran Nilai ORP.

Figure 8. ORP distribution.

Masukan nutrien yang berlebihan juga menjadi salah satu penyebab kematian ikan di Teluk Jakarta. Hujan berkepanjangan dari tanggal 23-28 November 2015 (Hasil diskusi dengan Dinas Kelautan, Perikanan dan Ketahanan Pangan Jakarta, 2015) dan hujan deras yang turun pada tanggal 29 November 2015 membawa limbah organik dalam jumlah besar, dimana dekomposisi bakteri terjadi dengan cepat (Anonim, 2003). Sebanyak 13 sungai besar bermuara ke Teluk Jakarta dan mengandung berbagai jenis limbah yang didominasi oleh limbah domestik (berasal dari pemukiman), yang diperkirakan memberi kontribusi sebesar 75\% terhadap pencemaran air di Teluk Jakarta (Prayitno, 2011). Limbah domestik berupa sampah anorganik akan menutupi permukaan air dan akan menghambat terjadinya proses fotosintesis, sedangkan limbah organik menyebabkan berkurangnya oksigen terlarut karena digunakan bakteri untuk proses dekomposisi, dan detergen yang sangat sukar diurai dapat meningkatkan kadar fosfat sehingga merangsang pertumbuhan alga yang berlebihan (Suhartono, 2009 dan Fried et al., 2003).Kadar fosfat hampir di semua lokasi penelitian telah melebihi baku mutu perairan untuk biota laut (Keputusan Menteri Negara Lingkungan Hidup nomor 51 tahun 2004 tentang Baku Mutu Air Laut) sebesar 0,015 mg/l (Gambar 5). Bahkan kandungan nitrat yang juga merangsang pertumbuhan algatelah melebihi baku mutu perairan sebesar $0,008 \mathrm{mg} / 1$ di semua titik penelitian (Gambar 4). Keputusan Menteri Negara Lingkungan Hidup nomor 51 tahun 2004 tentang Baku Mutu Air Laut disajikan pada lampiran 3 .

Tingginya kadar ammonia di perairan Teluk Jakarta menunjukkan bahwa lokasi ini sudah sangat tercemar dan tidak cocok untuk kehidupan organisme akuatik. Ammonia merupakan gas yang sangat beracun bagi ikan, dimana jika konsentrasinya lebih besar dari $3 \mathrm{mg} / \mathrm{l}$ akan menyebabkan kematian pada ikan, bahkan dengan konsentrasi $0,08 \mathrm{mg} / \mathrm{l}$ atau lebih besar akan menyebabkan toksisitas akut termasuk peningkatan respirasi (Amalfi, 2012). Pantai Ancol dan Muara Cilincing memiliki kadar ammonia tertinggi dibanding lokasi lainnya, yaitu lebih dari 0,8 mg/l (Gambar 6).

Ikan sembilang karang ((Plotosidae) sebagai salah satu indikator pencemaran perairan banyak yang mati saat peristiwa kematian masal ikan pada 30 November 2015. Ikan ini biasanya dapat mentolerir berbagai kondisi lingkungan dan temperatur (Lucas\& Southgate, 2012), sehingga dapat bertahan hidup bahkan pada kondisi kualitas air yang buruk (Anonim, 2008).

Diduga sumber kematian ikan berasal dari wilayah barat Teluk Jakarta. Kemunculan udang-udang yang mengapung di permukaan sejak tanggal 28-30 November di Muara Kamal juga menjadi indikasi persitiwa tersebut. Angin yang mengarah dari utara membawa ikan menuju ke wilayah paling selatan Teluk Jakarta yaitu Pantai Ancol. Pasang laut yang terjadi sebelum pukul 09.00 WIB membawa ikan-ikan tersebut ke Pantai Ancol yang hanya memiliki satu pintu keluar masuk air karena telah dibendung. Ikan-ikan ini pun akhirnya terisolir dan hanya terkonsentrasi di Pantai Ancol sehingga tidak ditemukan di wilayah perairan Teluk Jakarta lainnya.

Ledakan populasi fitoplankton tampaknya bukan menjadi penyebab terjadinya kematian masal ikan walaupun sebagai perairan eutrofik perairan Teluk Jakarta sangat kaya akan zat hara yang mendukung pertumbuhan fitoplankton (Nastiti \& Hartati, 2013). Chan (2016), menyatakan ledakan populasi fitoplankton bisa terjadi beberapa hari hingga beberapa minggu, sebelum kemudian fitoplankton mati dan menghilang karena faktor cuaca atupun fisika perairan. Pengambilan sampel fitoplankton yang dilakukan, 1-2 hari setelah kematian masal ikan tidak 
menunjukkan adanya ledakan populasi jenis fitoplankton tertentu yang dapat menyebabkan kematian ikan. Kelimpahan fitoplankton pada lima titik stasiun (st.1, st.5, st.8, st.10 dan st.11) berkisar antara 7-10.835 sel/1 dengan jenis yang mendominasi adalah Chaetoceros dari kelas Bacillariophyceae (Gambar 7). Nilai plankton ini tidak jauh berbeda dengan kelimpahan fitoplankton di Teluk Jakarta bulan Mei 2010 mencapai 79.270 sel/1 dengan jenis yang mendominasi adalah Chaetoceros (Prayitno, 2011). Jenis fitoplankton ini tidak beracun tetapi jika terjadiledakan dapat menyebabkan kematian pada ikan karena tersangkut di insang (Moore et al., 2011). Ledakan populasi fitoplankton yang menyebabkan kematian ikan dalam jumlah besar pernah terjadi di perairan Teluk Jakarta tahun 2004, dimana kelimpahan fitoplankton mencapai 4,2 x $10^{6}$ sel/1 dengan jenis yang melimpah adalah Chaetoceros, Skeletonema, Thalassiosira dan Prorocentrum (Thoha et al., 2007). Hasil penelusuran Rancak (2013), diketahui beberapa jenis plankton telah menyebabkan kematian ikan di Teluk Jakarta sejak beberapa dekade yaitu Dynophysis caudata, Noctiluca sp., Skeletonema costatum, Thalassiora mala, Chaetoceros Pseudocurvicetus dan Prorocentrum micans.

\section{KESIMPULAN}

Berdasarkan analisa dari 14 parameter fisika, kimia dan biologi perairan diketahui faktor penyebab kematian masal ikan di Teluk Jakarta pada 30 November 2015 adalah rendahnya kandungan oksigen terlarut (hanya 0,07 mg/1 pada lokasi pusat kematian ikan), kadar nutrien yang berlebihan (nitrat ,0,003-0,389 mg/l dan fosfat 0,811-1,653 $\mathrm{mg} / \mathrm{l}$,)dan tingginya konsentrasi ammonia yang merupakan gas beracun dan berbau (0,227-1,944 mg/l).

\section{PERSANTUNAN}

Penelitian ini merupakan bagian dari kegiatan penelitian crash program di Balai Penelitian Pemulihan dan Konservasi Sumberdaya Ikan. Penulis mengucapkan terima kasih kepada Prof. Dr. Krismono, MS., Prof. Dr. Ngurah N. Wiadnyana, Prof. Dr. Husnah dan Dr. Reny Puspasari atas komentar dan saran yang sangat berharga untuk penerbitan tulisan ini.

\section{DAFTAR PUSTAKA}

Amalfi, F.A. (2012). What cause fish kills? Part 2. Diakses dari http://www.aquaticconsulting.com/LFFISHKILL\%20Part\%202.pdf20 Januari 2016

Anonim. (2003). Fish kill investigation manual. Fishery Report No. 70 ISBN 072454705 3. Northern Teritory Government.
Anonim. (2008). Brown bullhead catfish code of practise. Diakses dari http://www.fish.govt.nz/en-nz/ Recreational/Most+Popular+Species/Catfish/ default.htm 25 Februari 2016.

Anonim. (2010). Hydrogen sulfide eruption along the Coast of Namibia.

Anonim. (2015). What is ORP? http://www. ozoneapplications.com/info/orp.htm.

Balai Penelitian Perikanan Laut. (2014). Pemantauan Perairan Laut dan Muara Teluk Jakarta. Bekerja sama dengan Badan Pengelolaan Lingkunan Hidup DKI, Jakarta. p. 30 .

Chan, B. (2016). Lake fly fishing tip: Understanding algal blooms. http://www.gofishbc.com/how-to-fish/ fishing-articles/understanding-algal-blooms.aspx.

Erlania, Rusmaedi, Prasetio, A.B., \& Haryadi, J. (2010). Dampak manajemen pakan dari kegiatan budidaya ikan nila (Oreochromis niloticus) di keramba jaring apung terhadap kualitas perairan Danau Maninjau. Prosiding Forum Inovasi Teknologi Akuakultur 2010, 621-631.

Fried, S., Mackie, B., \& Nothwehr, E. (2003). Nitrate and phosphate levels positively affect the growth of algae species found in Perry Pond. Tillers 4, 21-24.

Gerardi, M. H. (2007). Oxidation-reduction potential and wastewater treatment. New England Diakses dari http:/ /www.neiwpcc.org/iwr/reductionpotential.asp 25 Januari 2016.

Holmes-Farley, R. (2008). ORP and the reef aquarium. Diakses dari http://reefkeeping.com/issues/2003-12/ rhf/feature/.

Holmlund, C.M., \& Hammer, M. (1999). Ecosystem services generated by fish populations. Ecological Economics 29, 253-268.

Irawan, A., Hasani, Q., \& Yuliyanto, H. (2015). Fenomena Harmful Algal Blooms (HABs) di Pantai RinggungTeluk Lampung, pengaruhnya dengan tingkat kematian ikan yang dibudidayakan pada Karamba Jaring Apung. Jurnal Penelitian Pertanian Terapan 15 (1), 48-53.

Kantor Pengkajian Perkantoran dan Lingkungan (KPPL) DKI Jakarta. Interm Report. 1977

Kartamihardja, E.S. (2013). Fenomena dampak upwelling pada usaha budidaya ikan dengan KJA di danau dan waduk. Workshop Pengelolaan Lingkungan Perikanan 
Budidaya di Perairan Umum. Diakses dari http:// pusluh.kkp.go.id/mfce/download/al149.pdf.

Keputusan Menteri Lingkungan Hidup No. 51 Tahun 2004 tentang Baku Mutu Air Laut. Diakses dari http:// www.ppk-kp3k.kkp.go.id/ver2/media/download/ RE_keputusan-menteri-negara-lingkungan-hidupnomor-51-tahun-2004_20141008143942.pdf 15 Desember 2015.

La, V.T., \& Cooke, S.J. (2011). Advancing the science and practice of fish kill investigations. Review in Fisheries Science 18 (1), 21-33.

Lestari \& Edward, (2004). Dampak pencemaran logam berat terhadap kualitas air laut dan sumber daya perikanan (Studi kasus kematian massal ikan-ikan di Teluk Jakarta). Makara Sains. 8. (2), 56-62.

Lucas, J.S., \& Southgate, P.C. (2012). Aquaculture: farming aquatic animals and plants. John Wiley \& Sons. p.629.

Moore, S., Dusek, E., \& Trainer, V. (2011). Harmful Algal Blooms (HABs). http://faculty.washington.edu/pmacc/ $\mathrm{C} 1 \mathrm{a} \mathrm{s} \mathrm{s} \mathrm{e} \mathrm{s/E} \mathrm{s} \mathrm{t} 2011 / 1$ e c t u r e s / HAB\%20Intro\%20lecture\%20_2011.pdf.

Meyer, F.P., \& Herman, R.L. (1990). Interpreting the Scene. Field Manual for the Investigation of Fish Kills (F.P Meyer and L.A. Barclay, eds.). U.S. Fish and Wildlife Service resource publication 177. p. 125.

Nastiti, A.S., \& Hartati, S.T. (2013). Struktur komunitas plankton dan kondisi lingkunganperairan di Teluk Jakarta. BAWAL. 5 (3), 131-150.

Nasution, Z., Sari, Y. D., \& Huda, H.M. (2011). Perikanan budidaya di Danau Maninjau: antispasi kebijakan penanganan dampak kematian masal ikan. Jurnal Kebijakan Sosial Ekonomi Kelautan dan Perikanan $1(1), 19-31$.

Ohrel, Jr. R. L., \& Register. (2006). Volunteer estuary monitoring: a methods manual. Second Edition. The Ocean Concervacy. Diakses dari www.epa.gov. 18 November 2011.

Pidgeon, B. (2001). Natural causes of fish kills in Top End Waterways. Diakses dari https:// www.environment.gov.au/system/files/resources/ d13310f4-b5b6-411a-8f91-3245df48c190/files/fishkills.pdf 15 Februari 2016.
Prayitno, H.B. (2011). Kondisi trofik perairan Teluk Jakarta dan potensi terjadinya ledakan populasi alga berbahaya (HABs). Oseanologi dan Limnologi di Indonesia. 37(2), 247-262.

Rahmani, U., Syaukat, Y., Fauzi, A., \& Hidayat, A. (2011). Internalisasi biaya lingkungan pada budidaya ikan karamba jaring apung di Waduk Cirata. IndonesianJournal of Agriculture Economics. 2(2), 157-168.

Rancak, G.T. (2013). Pencemaran laut akibat HABs di Teluk Jakarta (p. 20). Program Pascasarjana Teknik Manajemen Pantai, Fakultas Teknologi Kelautan, Institut Teknologi Sepuluh November.

Sachoemar, I.S., \& Wahjono, H.D. (2007). Kondisi Pencemaran perairan Teluk Jakarta. JAI 3 (1). p. 14.

Suhartono, E. (2009). Identifikasi kualitas perairan pantai akibat limbah domestik pada monsun timur dengan metode indeks pencemaran (studi kasus di Jakarta, Semarang, dan Jepara). Wahana Teknik Sipil. 14(1), 51-62.

Suprapto, Kembaren, D., \& Lestari, P. (2011). Kondisi Lingkungan Perairan Teluk Jakarta . Balai Penelitian Perikanan Laut. Jakarta.

Suryanto. (2015). Sekitar 16,5 ton ikan Danau Maninjau mati mendadak. http://www.antaranews.com/berita/ 478107/sekitar-165-ton-ikan-danau-maninjau-matimendadak diakses dari 19 Januari 2016.

Suryati, N.K., \& Samuel. (2012). Fungsi Strategis Danau Batur, Perubahan Ekosistem dan Masalah yang Terjadi. Prosiding Seminar Nasional Limnologi. VI, 287-295.

Thoha, H., Adnan, Q., Sidabutar, T., \& Sugestiningsih. (2007). Note on the occurence of phytoplankton and its relation with mass mortality in the Jakarta Bay, May and November 2004. Makara, Sains, 11(2), 63-67.

Thronson, A., \& Quigg, A. (2008). Fifty-Five years of fish kills in Coastal texas. Estuaries and Coasts 31, 802813.

www.accuweather.com/id/id/jakarta/208971/month/ 208971?monyr=11/01/2015. 
Putri, M. R. A., et al. / BAWAL. 8 (2) Agustus 2016: 77-90

Xu, J., Xia, C., Zhou, Z., Li, Y., Zhang, F., \& Huang, T. (2016). Characteristic of pollutants released from reservoir sediments. Huang, T (Ed.). Water Pollution and Water Quality Control of Selected Chinese Reservoir Basins. p. 514.
Yatim, S., Surtipanti, S., Suwirna, S., \& Lubis, E. (1979). Distribusi logam berat dalam air permukaan Teluk Jakarta. Majalah Batan 12 (3), 1-19. 
Lampiran 1. Jenis dan kelimpahan fitoplankton yang ditemukan di perairan Teluk Jakarta Appendix 1. Phytoplankton species and its abundance found in Jakarta bay waters

\begin{tabular}{|c|c|c|c|c|c|}
\hline \multirow[b]{2}{*}{ KELAS DAN GENUS } & \multicolumn{5}{|c|}{ Kelimpahan fitoplankton/ Abundance of phytoplankton (sel/I) } \\
\hline & Tj. Kait & Muara Kamal & Muara Baru & Muara Ancol & Pantai Ancol \\
\hline Scenedesmus sp & & 20 & & & \\
\hline Bacteriastrum sp. & 14 & & 241 & 219 & 64 \\
\hline Cerataulina sp. & 64 & & & 134 & \\
\hline Chaetoceros sp. & 10,835 & 4,447 & 2,144 & 2,753 & 835 \\
\hline Cococcneis sp. & & 4 & & & \\
\hline Coscinodiscus sp. & 28 & 95 & 616 & 934 & 481 \\
\hline Cyclotella sp. & 85 & 37 & & & \\
\hline Guinardia sp. & & 3 & 92 & & \\
\hline Hemiaulus sp. & 99 & & & & \\
\hline Lauderia sp. & & & & 7 & \\
\hline Leptocylindrus sp. & 510 & & & & \\
\hline Melosira sp. & 35 & & & & \\
\hline Navicula sp. & & 1 & 21 & & \\
\hline Nitzchia sp. & 3,588 & 1,414 & 970 & 2,109 & 219 \\
\hline Pleurosigma sp. & & & & & 14 \\
\hline Rhizosolenia sp. & 269 & 495 & 7 & 14 & \\
\hline Skeletonema sp. & & & 28 & 177 & 786 \\
\hline Strepthoteca sp. & & 1 & & 7 & \\
\hline Thalassionema sp. & 50 & & & & \\
\hline Thalassiosira sp. & - & 283 & 1,302 & 1,076 & 510 \\
\hline Thalassiothrix sp. & 113 & 11 & & & \\
\hline Ceratium sp. & & & 219 & 127 & 64 \\
\hline Protoperidinium sp. & 21 & 8 & 212 & 156 & 35 \\
\hline Prorocentrum sp. & 42 & & 7 & & 21 \\
\hline Pryrocistis sp. & 35 & & & & \\
\hline Pyrophacus sp. & & & 7 & & \\
\hline
\end{tabular}


Lampiran 2. Kondisi suhu DKI Jakarta, November 2015, (www.accuweather.com)

Appendix 2. Temperature condition of Jakarta, November 2015, (www.accuweather.com).

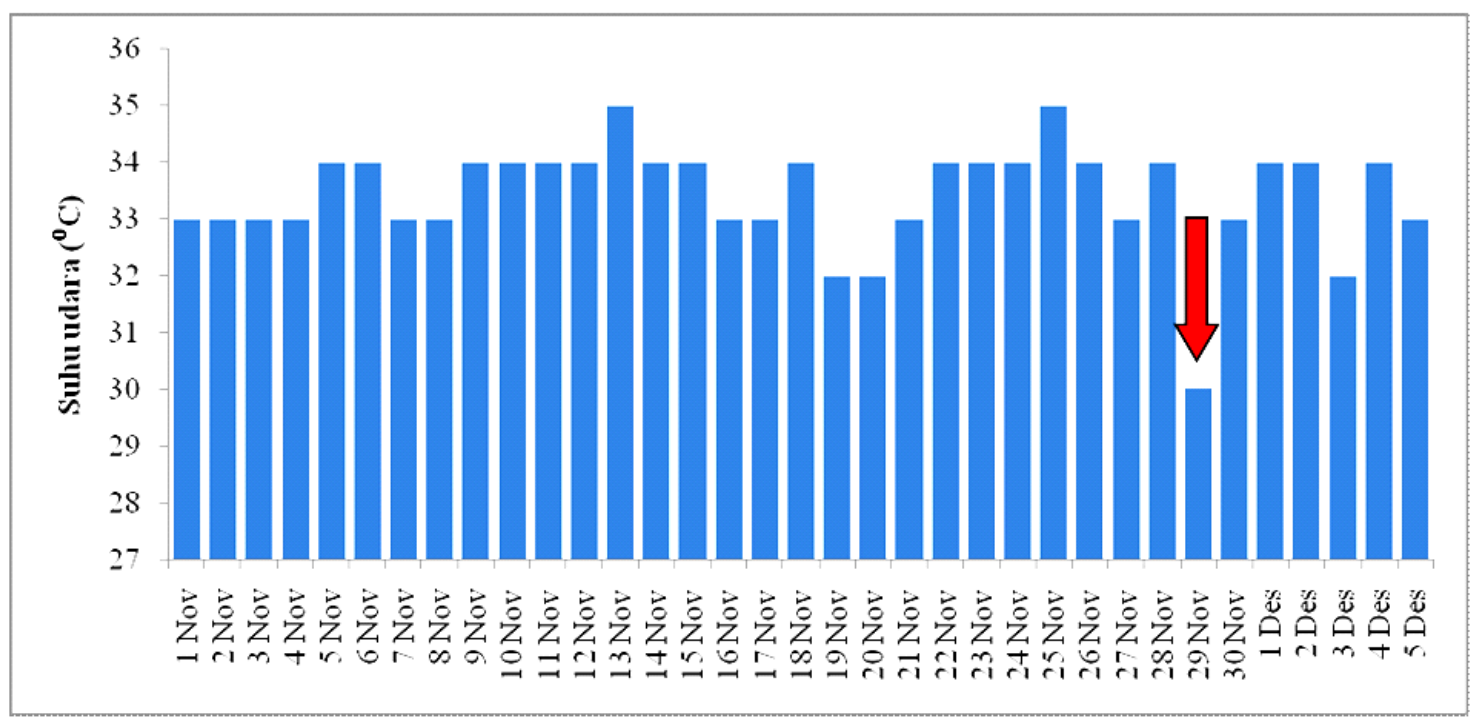

Lampiran 3. Baku mutu parameter perairan (quality standards of water parameter)

Appendix 3. Raw water quality parameters (quality standards of water parameters)

\begin{tabular}{lc}
\hline Parameter perairan/ water parameter & Baku Mutu/quality standards* \\
\hline Kecerahan/transparency $(\mathrm{m})$ & (mangrove) \\
Suhu air/water temperature $\left({ }^{\circ} \mathrm{C}\right)$ & $28-32$ \\
$\mathrm{pH}$ & $7-8,5$ \\
Salinitas/salinity $(\%)$ & $\mathrm{s} / \mathrm{d} 34$ \\
Oksigen terlarut/Dissolved oxygen (mg/l) & $>5$ \\
Nitrat/Nitrate (mg/l) & 0,008 \\
Ortoposfat/Orthophosphate (mg/l) & 0,015 \\
Ammonia/Ammonia(mg/l) & 0,3 \\
BOD 5 (mg/l) & 20 \\
TSS (mg/l) & 80 \\
Sulpida/ Sulphide (mg/l) & 0,01 \\
Fitoplankton/phytoplankton (sel/l) & tidak bloom \\
\hline
\end{tabular}

* Keputusan Menteri Lingkungan Hidup No. 51 Tahun 2004 tentang Baku Mutu Air Laut. 